\title{
SOCIO-LEGAL ASPECTS OF RACIALLY MOTIVATED POLICE MISCONDUCT
}

It is generally conceded that the problem of racially discriminatory law enforcement has improved in the last twenty-five years. ${ }^{1}$ This concession, however, is more of an indictment of the past than an approbation of the present. The 1964 New York riot and the 1967 Tampa civil upheaval were both triggered by the application of lethal force by white policemen on black subjects. ${ }^{2}$ While incidents like Jackson State ${ }^{3}$ invoke the nation's attention, the real tragedy lies in the low-profile day-to-day conflict between police and black members of the ghetto. The purpose of this comment is to analyze the psycho-sociological causes of racially motivated police misconduct ${ }^{4}$ and examine the federal civil remedies available for redress of such

1. See, e.g., A. Niederhoffer, Behind the Shield: The Police In Urban Society (Anchor ed. 1969) [hereinafter cited as Niederhoffer]. See generally The President's Commission on Law Enforcement and Administration of Justice: Task Force Report: The POLICE 181-82 (1967) [hereinafter cited as TASK ForCe: The POLICE].

THE FOLLOWING ADDITIONAL HEREINAFTER CITATIONS WILL BE USED IN THIS COMMENT:

Report of the National Advisory Commission on Civil Disorder (1968) [hereinafter cited as KERNER COMM'N REP.];

J. Skolnick, Justice Without Trial: Law Enforcement in Democratic Society (1966) [hereinafter cited as SKOLNICK];

Fogelson, From Resentment to Confrontation: The Police. The Negroes, and the Outbreak of the Nineteen-Sixties Riots, 83 PoL. Sc1. Q. 217 (1968) [hereinafter cited as Fogelson];

Hahn \& Feagin, Riot-Precipitating Police Practices: Attitudes in Urban Ghettos, 31 Phylon 183 (1970) [hereinafter cited as Hahn \& Feagin];

Rinella, Police Brutality and Racial Prejudice: A First Close Look, 45 J. URBAN L. 773 (1968) [hereinafter cited as Rinella].

2. See Kerner Comm'n Rep. 1-3, 1-I5 to -25. See generally Fogelson 217-19; Hahn, Cops and Rioters: Ghetto Perceptions of Social Conflict and Control, 13 AM. BeHAv. Scientist 761, $762-63$ (1970); Rinella 794.

3. The Report of the President's Commission on Campus Unrest 411 (1970) (Scranton Comm'n Rep.) vividly described the Jackson State tragedy:

Two nights of campus demonstrations at Jackson State College in May 1970 ended in

violent confrontation and tragedy. After 28 seconds of gunfire by Mississippi Highway

Safety Patrolmen and Jackson city policemen, two black youths lay dying and 12 others were wounded.

4. The problems of racial discrimination in housing, employment, and recreation have been treated extensively, but until recently the issue of racially motivated police misconduct has received scant attention. Hahn \& Feagin 183; Levy, Cops in the Ghetto: A Problem of the Police System, 11 Aм. BeHAV. SCIENTIST 31, 33 (1968). 
misconduct under Title 42 United States Code sections 1981 and 1983 derived respectively from the 1866 Civil Rights Act $^{5}$ and the 1871 Civil Rights Act. ${ }^{6}$

\section{The Psycho-Sociological Characteristics of Racially DISCRIMINATORY LAW ENFORCEMENT}

To appreciate properly the nature of the problem posed by this comment, it is necessary to understand what transpires when a white patrolman walks into a black ghetto. First, one must grasp the type of policeman who usually confronts urban Negroes.

\section{Development of the Law Enforcement Personality}

While it is impossible to sketch a flawless portrait of the "typical" policeman, statistical studies have identified certain common characteristics inuring to the vast majority of police. Most individuals considering law enforcement as a career perceive this vocation as a prestigious step from their working class background ${ }^{7}$ toward middle class respectability and economic security. However, police candidates characteristically exhibit strong racial prejudice ${ }^{8}$ and early studies indicated that police recruits were often of below average intelligence. ${ }^{9}$ Most large city police departments now matriculate persons with a mean I.Q. of 100 to $105^{10}$ although ninety-five percent of all police candidates have received no college training."

Before an individual becomes a policeman he may be subjected to a battery of intelligence, psychological, emotional, and character

5. Act of April 9, 1866, ch. 31, \& 1, 14 Stat. 27, re-enacted, Enforcement Act of [May 31] 1870, ch. 114, §18. 16 Stat. 140, 144, codified, Revised Statutes of 1878. § 1977 (2d ed.), now. 42 U.S.C. $\S 1981$ (1964).

6. Ku Klux Klan Act of April 20. 1871, ch. 22, § 1, 17 Stat. 13, codified, Revised Statutes of 1878, $\S 1979$ (2d ed.), now, 42 U.S.C. 1983 (1964).

T. See Niederhoffer 150. See also Cross, The Negro. Prejudice, and the Police, 55 J. Crim. L.C. \& P.S. 405, 407 (1964).

8. See SKOLNICK 80-83.

9. E.g.. Thurstone. The Intelligence of Policemen, 1 J. Personnel Research 64 (1922).

10. NiEDERHOFEER 148.

11. Id. 39. But see TASK Force: The Police 10 citing a national survey concluding that 24 percent of patrolmen and 31 percent of top-level department administrators have some college education. Nearly four decades ago, a prominent New York Police Chief decried the lack of highly trained police and advocated that the federal government establish a four year college that would award graduates a Bachelor of Police Science degree. This college, like West Point and Annapolis. would bear the full tuition of each candidate and would provide an "army against an enemy from within." Speech from Andrew J. Kavanaugh to Att'y General's Conference on Crime. Dec. 13, 1934. 
examinations, ${ }^{12}$ but only a few police departments test for racial prejudice. ${ }^{13}$ One commentator has described how the candidate, having passed this first battery of tests, is then devastated by his experience at a police academy. ${ }^{14}$

The purpose of the academy is to train the recruit for his new role of law enforcement. He is taught a gamut of subjects ranging from law and government, first aid, and marksmanship to proper wearing of the uniform. ${ }^{15}$ The recruit is also indoctrinated in the underlying ideals, aspirations, and professionalism which supposedly characterize a police department. The disparity, however, between the ideals of the academy and the experiences gleaned from veteran police officers engenders an attitude of cynicism in the young policeman. ${ }^{16}$ The more experienced police admonish the new patrolmen to "be tough," to disregard the social and philosophic doctrines of the academy, and to remain alert to the fact that a patrolman is evaluated by his arrest record, not his adherence to criminal procedural safeguards. ${ }^{17}$

The newly commissioned policeman thus begins his career uncertain as to the propriety of adopting the crime control or due process of law enforcement model. ${ }^{18}$ This attitudinal tension between

12. Niederhoffer 35-38. But see TASK ForCe: The Police 10. Despite the high failure rate incident to current police selection procedures, it is probable that current screening processes eliminate potentially excellent police while admitting poorly disposed individuals. Character investigations rarely canvass the proper scope or depth necessary to obtain information permitting professional evaluation, and presently employed psychiatric examinations are inadequate to detect personality defects which will inhibit judicious law enforcement under the stress of police work. Id. at 128-31. Conversely, certain screening processes preclude potentially exemplary personnel. Physical, age, and residency requirements should be relaxed. Most police departments require that an applicant have obtained majority. This excludes recent high school graduates who must embark upon another career, probably never again to consider being a policeman.

13. TASK Force: The Police 164. The lack of attention devoted to the necessity of screening out racially biased police is illustrated by R. Perkins, Police Examinations (1947). This elaborate book coutainś a comprehensive set of tests enabling administrators to evaluate police personnel. But despite the book's thoroughness, it contains not one question testing for racial prejudice.

14. NIEDERHOFfER 43-51.

15. Id. at $44-45$.

16. Id. at 46.

17. Id. at $56,75-77$.

18. See generally Packer. Two Models of the Criminal Process, 113 U. PA. L. Rev. 1 (1964). "[T]he Crime Control Model is based on the proposition that the repression of criminal conduct is by far the most important function to be performed by the criminal process." Id. at 9. "If the Crime Control Model resembles an assembly line, the Due Process Model looks very much like an obstacle course. Each of its successive stages is designed to present formidable impediments to carrying the accused any further along the process." Id. at 13. 
idealism and pragmatism is compounded when the policeman is assigned to the "beat." To his chagrin he discovers in his constant contacts with petty offenders and law-abiding citizens alike that he is regarded with little prestige and considered lower class. ${ }^{19}$ Indeed, a recent study of the status accorded various occupations ranked police fifty-fourth out of ninety along with railroad conductors and playground instructors. ${ }^{20}$

The first assignment for nearly every new policeman is that of foot patrolman. This task, albeit valuable as a device to assist young policemen in gaining an awareness of the neighborhood, is a source of frustration. The menial and dirty chores fall to the novice patrolman, whereas the glamorous and most immediately significant cases such as homicide are pre-empted by ranking officers in the Detective Division. ${ }^{21}$ The demeaning nature of the foot patrolman's duty does not preclude serious responsibility, however, and when this is combined with the additional elements of scant prestige and slight recognition, the patrolman becomes embittered and apathetic. ${ }^{22}$ The new policeman develops an anomic ${ }^{23}$ perception of society, losing his faith in people, his enthusiasm for high police ideals, and his sense of pride and integrity. ${ }^{24}$

The young policeman's severe symptoms of anomie, while not entirely dissipating, gradually level off as his mental processes

19. See. e.g., Skol.vick 49-51; Rudwick, Police Work and the Negro. 50 J. CRiM. L.C. \& P.S. 596-97 (1960).

20. A. Reiss. Occupations and Social Status 56 (1961). "The low status of the police is almost res judicata." Niederhoffer 21. In Allor v. Board of Auditors, 43 Mich. 76, 98.4 N.W. 492. 497 (1880). the Michigan Supreme Court stated: "The police force is nothing more nor less ... than an additional force of constables and watchmen appointed by the State for certain limited purposes...."

21. Niederhoffer 62.

22. ld. at 63. In Mark. A Police Point of View, 38 Medico-Legal J. 4.10 (1970), the task of the young policeman is colorfully described:

... To [sic] take a knife off a drunk or a shotgun off a jailbreaker, to settle a bitter fight between two aging queers who want to chuck one another on to the street. to soothe a woman whose husband has just hit her with a broken bottle, to do something for a child that nobody's bothered to feed for a week. to question a pregnant teenager who's tried to open her wrist with a chisel, to pick up an addict in terminal deterioration, to stop a white landlord from braining a black tenant, or vice-versa: they expect 20-year old coppers to do that.

23. Anomie is a "state of mind characterized by a sense of rootlessness." J. VA.NDt:R ZANDEN. SOCIOLOGY: A SYSTEMATIC APPROACH 52 (1965). One source of anomite is particularly appropriate to the policeman's situation. Anomie results from the "disparity between the goals held out to the members of a society and the institutionalized means by which these goals may be achieved." $I d$. at 53 .

24. NIEDERHOFFER 96. 
struggle to maintain homeostasis. ${ }^{25}$ The patrolman, through experiences and the passage of time, toughens his mental skin, withdraws from society, ${ }^{26}$ and seeks solace in the semi-military police system. The nature of his occupation impedes gratifying social relationships, even off-duty, with anyone other than members of fellow police families. ${ }^{27}$ The policeman's neighbors decline intimate friendships, fearing perhaps that casual and inadvertent references to extralegal conduct will result in judicial sanctions. Thus confined to a "police society," the policeman's occupation becomes not merely a job, but a life style. ${ }^{28}$ Moreover, in response to the concomitant presence of danger, authority, and efficiency, the policeman develops a "working personality." 29

\section{The Working Personality}

The first ubiquitous element in the policeman's working milieu is danger. The constant uncertainty as to when police will be accosted by insanity or violence magnifies the impact of this danger on the policeman's psyche. Superimposed upon this environment of danger is the police bureaucracy's requirement for efficiency. Despite the denial of top-echelon police officials, it is generally acknowledged that quota systems do exist. ${ }^{30}$ Such systems, for example, - require a policeman patrolling a given district to issue a specified number of tickets within a given time period. When the system is applied in a black ghetto, whose residents perceive police as a symbol of white society, ${ }^{31}$ friction and ill-will increase alarmingly.

Of the three elements shaping the working personality-danger, efficiency, and authority - the most dominant is authority. Police solidarity fosters the crime control mode ${ }^{32}$ of the criminal process at the expense of constitutional procedural requirements. ${ }^{33}$ The police

25. See generally F. RuCH, Psychology and Life 63 (6th ed. 1963).

26. '"Policemen,' pointed out H.L. Mencken, 'enjoy a social life almost as inbred as that of Justices of the United States."' S. Asch, Police Authority and the Rights of the INDIVIDUAL 34 (1967). See also Clark, Isolation of the Police: A Comparison of the British and American Situations. 56 J. CRIM. L.C. \& P.S. 307 (1965); Mills, Commentary on the Symposium. 60 J."CRIM. L.C. \& P.S. 256 (1969) ("[P]olice have sometimes pictured themselves as a persecuted minority . . . ; police have termed themselves 'the blue race."').

27. S. Asch, supra note 26 , at 34 .

28. SKOLNiCK 43.

29. Id. $42-70$.

30. CS. Kerner Comm's Rep. 11-13.

31. See note 111 infra and accompanying text.

32. See note 18 supra.

33. Cf. SKolnick 67. 
look with great disfavor upon any attempt to challenge or discredit their self-image of authoritarianism ${ }^{34}$ nurtured by their limited societal perspective. Indeed, a study of the police personality found defiance to police authority to be a reason for physical response by police. ${ }^{35}$ The explanation of this practice which severely erodes policecivilian relations is seated in a basic psychological concept. Every individual has a notion of the personality he presents to others, but, more importantly, he entertains a conception of how he believes other people perceive him $^{36}$ - a conception which he consciously and subconsciously strives to maintain in the face of attack. ${ }^{37}$ The police, a semi-military organization, harbor a self-image of authoritarianism ${ }^{38}$ and forcibly rebuke any act challenging the integrity of such an image. This authoritarianism further alienates the police from society, thus accentuating police solidarity ${ }^{39}$ and the self-feeding process of increased authoritarianism.

A key element of the authoritarian personality is conventionalism, a chauvinistic loyalty to middle class values. ${ }^{40^{\circ}}$ Given this political and normative philosophy, it is easy to understand why police disparage the lower-class morality often displayed by most black ghetto residents ${ }^{41}$ and why they exhibit less respect for these blacks than for white suburbanites. The typical policeman identifies with short hair and business suits and the mere sight of afros and head scarves triggers hostility. ${ }^{22}$

Closely analogous to this adherence to middle-class conventionality is the police attribute of political conservatism, as evidenced

34. Fogelson 230 .

35. Westley, Violence and the Police, 59 AM. J. Soc. 34, 38 (1953).

36. F. Ruch. supra note 25 , at 125.

37. Id. at 63. A process termed "looking-glass self" is closely related to the concept of selfimage. The initial stage in this process occurs when we develop an image of how we appear to others. We then imagine how this appearance is judged by others. Finally, we emotionally react to what we imagined others judged us to be. If police erroneously evaluate how others think and judge them, their subsequent conduct will probably be inapposite. J. VANDER ZANDEN, supra note 23, at 246-47.

38. E.g. Fogelson 230.

39. SKOLNICK 52-58.

40. T. Adorio, E. Frenkel-Brunswick. D. Levinson \& R. Saniord, The Authoritarian Personality 228-30 (1950) (American Jewish Committec).

41. Rinella 783. See Allen, Pilnick \& Silverzweig, Conflict Resolution--Team Building for Police and Ghento Residents, 60 J. CRIM. L.C. \& P.S. 25I, 253 (1969) ("“[A] police-held norm about the ghetto [is that] . . . there is a general low standard of morality among the people of the 'ghetto").

42. See Werthman \& Piliavin, Gang Members and the Police, in TH: Pol.tce 80 (D. Bordua ed. 1967), cited in TASK FoRCE: THE POLICE 185. 
by support of George Wallace in the 1968 Presidential campaign. ${ }^{43}$ Police, if not members of the John Birch Society, are often sympathetic to the organization's philosophy, ${ }^{44}$ which includes elements of racial and religious prejudice. ${ }^{15}$ It is difficult to perceive how a policeman wholeheartedly supporting the Society's platform could act impartially and judiciously when confronted with an insolent, yet law-abiding, black youth.

Despite the policeman's disposition toward conventionalism, he seldom exhibits strong puritanical morality. ${ }^{46}$ As guardians of dominant social mores, however, police are required to enforce middle-class morality reflected in crimes such as drunkenness, statutory rape, ${ }^{47}$ and public profanity. The disparity between the policeman's disposition and his law enforcement duties thus leaves him vulnerable to the charge of hypocrisy.

\section{Ghetto Perceptions, Police Professionalism, and Black Police}

Another significant police characteristic pertinent to the ability to perform equitably and efficiently in a black community is perception of the ghetto resident. The issue here is whether police react with verbal and physical abuse to actual or to merely imagined black hostility. If the reaction is to the latter, the police perceptions of ghetto hostility have engendered a self-fulfilling prophecy of discordant relations. ${ }^{48}$ In 1968 the Kerner Commission canvassed 15 major cities to ascertain police perceptions of ghetto hostility ${ }^{49}$ and found that police believed 31 percent of the population to be hostile to law enforcement agencies. ${ }^{50}$ The study concluded that the degree of hostility perceived by police was much higher than actually existed. ${ }^{51}$

43. See, e.g., Walsh, Professionalism and the Police, 13 Am. Behav. Scientist 705, 708-12 (1970). Conservative politicans generally support existing power and social structures, thus reflecting an acceptance of authority. This conservative ideology tends to coincide with "conventional" rather than rebellious social values. See Authoritarian Personality, supra note 40, at 162; SKOLNICK 61.

44. See S. AsCH, supra note 26, at 32-34; NIEDERHOFFER 117-21.

45. See Westin, The John Birch Society, 32 COMmeNTARy 93, 95, 101-03 (1961).

46. Skolnick 57.

47. The Westiville, California, morals squad once reflected unanimous opposition to enforcement of a statutory rape statute since they admitted that they might have availed themselves of an attractive, willing, 17 year old girl when they were young. Id. at 57.

48. See generally Groves \& Rossi, Police Perceptions of a Hostile Ghetto. 13 AM. BeHAv. SCIENTIST 727. 728 (1970).

49. Id. at 731 .

50. ld. at 732 .

51. Id. at 741 . 
Various categories of police, however, were more in contact with reality than others. The police with the most intense quantum of perceived hostility were highly prejudiced, young, white, ${ }^{52}$ and unacquainted with ghetto residents. Correlatively, veteran police, entertaining only slight racial prejudices and knowledgeable of ghetto residents were least likely to espouse hostility. The "acquaintance" variable is particularly interesting since, contrary to the British system, most American police departments prohibit a policeman from living in the neighborhood which he patrols. The rationale underlying this policy is that a policeman who becomes too friendly with his neighbors will be inhibited in the impartial enforcement of the law. This reasoning is of questionable validity since many civilians shun police anyway, ${ }^{53}$ and a modicum of familiarity with residents leads to improved community relations and more effective law enforcement. ${ }^{54}$ The other important variable, prejudice, could be eliminated by subjecting all police recruits to a prejudice examination when they apply to join the force. ${ }^{55}$ Any individual found highly prejudiced should be disqualified.

This comment has thus far examined the "typical" policeman as depicted by sociological and psychological studies. Policemen, like members of any other profession, exhibit individual differences and nuances. One major criterion, the division between low-professional and high-professional police, egregiously segregates police into two camps. The advocates of a highly professional police force envision a core of college educated, highly disciplined individuals devoid of strong racial prejudices, concerned with balancing procedural safeguards and effective law enforcement. ${ }^{56}$ Highly professional police differ from their less professional brothers in certain respects. They are less likely to brutalize suspects, ${ }^{57}$ or to project racial prejudice. ${ }^{58}$

52. Id. at 732. Once the variable of prejudice was accounted for, however, the factor of whether the policeman was white or black became insignificant.

53. See note 27 supra and accompanying text.

54. E.g. TASK Force: The Police 144.

55. See note 13 supra and accompanying text.

56. NIEDERHOFHER 16-20.

57. Walsh. supra note 43. at 714. Fifty-two percent of highly professional police felt justified in roughing up a man to effect an arrest, whereas only seven percent felt force was appropriate when an individual looked or talked tough to the policeman. In contrast. 45 percent of low professional police felt justified in roughing up a man in the latter case. Id. at 713 (Table 3).

58. Fifty-seven percent of the police who had a low level of professionalism considered racial and social class as a justifiable distinguishing factor for determining when to use force. Only twenty percent of the highly professional police responded in the same manner. /d. at 716 (Table $5)$. 
At the present time, however, low-professional police numerically dominate most departments. Yet, even if a statistically small number of police meet highly professional criteria, a wise allocation of such police to ghetto areas would maximize harmonious community relations. Unfortunately, the most authoritarian, ${ }^{59}$ aggressive, and prejudiced ${ }^{60}$ police on most forces are presently assigned to patrol the troublesome black neighborhoods. That pernicious community relationships will follow is almost axiomatic.

Race is another palpable difference dividing police into distinct camps. The division between white and black policemen was once minuscule for the simple reason that Negroes were systematically precluded from becoming police. ${ }^{61}$ In 1940 there were no black policemen in the five southern states containing the largest Negro populations, ${ }^{62}$ and as late as 1960 only 3.5 percent of all law enforcement personnel in the entire nation were non-Caucasian. ${ }^{63} \mathrm{By}$ 1962 there were only 36 black state policemen throughout the United States, and 24 were located in Illinois. ${ }^{64}$ These conditions have been ameliorated somewhat as several cities have recently initiated intense recruitment programs to secure more black police, but Negroes still remain drastically under-represented in every level of municipal, state, and federal law enforcement. ${ }^{65}$ This under-representation stems from discriminatory selection procedures and the dearth of qualified

59. NIEDERHOFFER 137-39.

60. KeRner COMm'N REP. 11-15. Police while routinely performing their duties utter nearly every derisive Negro colloquy known to man. The chief of the Westville, California, Police Department promulgated the following order:

As a matter of policy, the following words and other similar derogatory words shall not be used by members and employees in the course of their official duties or any other time as to bring the Westville Police Department into disrepute. These words are: boy, spade, jig, nigger, blue, smoke, coon, spook, headhunter, junglebunny, boogie, stud, burrhead, cat, black boy, black, shine, ape, spick, mau-mau. The most common display of a lack of courtesy or objectivity is the use by an officer of unsuitable or offensive language or mannerisms.

There is particular need to refrain from language which has derogatory connotation with reference to race, color, religion, or nationality. Such usage by the police causes deep resentments and antagonism against them. SKoLNick 80-81.

61. See Task Force: The Police 167-71.

62. Rudwick, The Negro Policeman in the South, 51 J. CRIM. L.C. \& P.S. 273 (1960). Even those southern states with black police restricted their duties to arresting white felons and not white misdemeanants. It was feared Negro police vested with the latter power might become "uppity." Id. at 275.

63. TASK Force: The Police 10.

64. Id. at 10 \& n.42, citing United States Commission on Civil Rights, Administration OF JUSTICE (staff report draft 1963) 13-16.

65. Id. at 10 \& n.43, 168; KeRner COMM'N ReP. $11-39$ to -40. 
Negroes interested in joining a police force. ${ }^{66}$ Moreover, officials advocating a highly professional cadre of police officers resist massive Negro recruitment programs, which require lowered entrance standards to accommodate the shortage of qualified Negroes. ${ }^{67}$ Additional factors militating against greater representation of Negroes on police forces are the potential stigma of being labeled an "Uncle Tom" and the practice of discriminatorily assigning black police unfavorable duties. ${ }^{68}$

Assuming a Negro becomes a policeman and is assigned to patrol a black neighborhood, how efficaciously does he perform his duties? Black police might be expected to be overly harsh on black residents because of a felt need not to be considered predisposed toward Negroes. But, in general, black police more realistically perceive actual ghetto hostility, ${ }^{69}$ more readily command the respect of black citizens, more successfully acquire ghetto information, more intuitively understand ghetto moods, and more expeditiously detect trouble than their white counterparts. ${ }^{70} \mathrm{~A}$ policeman's conduct toward a given individual should be triggered by the determination of whether that individual falls within law-obeying or law-violating categories, not whether he is of the same racial group as the policeman. A recent study, however, reports that there is a positive correlation between the racial background of a policeman and the degree of familiarity he will tolerate from an individual of the same racial group. ${ }^{71}$ Stated succinctly, black police accept greater harassment from black residents before responding with hostility than do white police. The direct consequence to the ghetto of more emphatic police personel is less inimical interaction between police and citizens.

\section{Counterproductive Police Practices In Black NEIGHBORHOODS}

The previous section attempted to identify and evaluate the psycho-sociological characteristics of most policemen. This section

66. TASK Force: The Police 168-69.

67. NiEDERHOfFER 196.

68. Negro police are usually assigned to foot patrols rather than desk jobs and by-passed for promotion. TASK ForCe: The Police 171-73.

69. Groves \& Rossi, supra note 48 . at 732.

70. See TASK Force: The Police 167.

71. Scott, Racial Group Membership. Role Orientation, and Police Conduct Among Lirban Policemen, 31 PHyLoN 5. 10 (1970). 
will attempt to portray the counterproductive manifestations arising from these personality attributes.

\section{Physical Brutality}

Most people envision physical excesses as the most common and deleterious type of conduct employed by police to harass Negroes. While physical brutality has been a serious problem in the past-and remains a serious problem in parts of the South-the problem is now less severe. ${ }^{72}$ As noted previously, the primary event triggering unwarranted physical excesses by police is a challenge to their authority. ${ }^{73}$ Because juveniles are particularly eager to prove their manliness and nerve, they frequently decline to submit to a policeman's assertion of authority. ${ }^{74}$ This problem is further exacerbated by the fact that the mean age in most ghettos is under $21^{75}$ although several police departments have responded to this wave of juvenile hubris by condoning youth harassment. ${ }^{76}$ In addition to juveniles certain other classes of Negroes provoke prejudiced policemen by their mere presence. Black "studs" and black men with white dates are regarded as "symbolic assailants" and are particularly vulnerable to police hostility. ${ }^{77}$

\section{Verbal Abuse}

The major source of citizen complaints is not physical excesses, but verbal abuse of an "ethnic nature." brutality is particularly abrasive when directed toward black women or juveniles. ${ }^{79}$ Youths are especially insecure, mercurial, and defensive concerning insinuations demeaning their self-dignity and are likely to object to any verbal attack. The tone of voice employed by the officer may evoke a visceral response from the object of the abuse. The issue involved, the "dignity and respect due to each individual from his

72. TASK ForCe: THe POLICE 181-82.

73. See notes $34 \& 57$ supra and accompanying text.

74. Kerner Comm'n ReP. 11-10; Weiler, "Who Shall Watch the Watchmen?" Reflections on Some Recent Literature About the Police, II CRIM. L.Q. 420, 428 (1969).

75. KerNer COMM'N REP. 11-10.

76. Id.

77. See Crockett, Racism in the Law, 33 Scl. \& Soc. 223, 227 (1969).

78. See W. Gellhorn, When Americans Complain 177-78 (1966); Weiler, supra note 74, at 424-25.

79. See W. Gellhorn, supra note 78, at 177-78 n.77 (1966); KeRNer COMm'N ReP. I1-09 to -11; Reich. Police Questioning of Law Abiding Citizens, 75 YALE L.J. 1161, 1165 (1966). 
government," 80 is of no small import in light of the increased pride exhibited by Negroes in their history, culture, and heritage. ${ }^{81}$ Most police use a wide array of biting epithets in the ordinary performance of their duties. ${ }^{82}$ Part of this phenomenon is attributable to the fact that police by nature shun euphemisms $;^{83}$ but since the consequences of verbal abuse are so inimical to objective, racially unbiased law enforcement, some police departments have ordered an end to such conduct. ${ }^{84} \mathrm{~A}$ final form of verbal abuse provoking black hostility and counter-prejudices is the police practice of refusing to address Negroes by an appropriate prefix such as Mister or Miss and the use of an individual's first name rather than his last. ${ }^{85}$ The goal of amiable police-ghetto relationships is unattainable as long as verbal insults impinge upon the dignity of black citizens. Since naked prejudice underpins most verbal assaults, it is easy to understand why overreaction often follows.

\section{Police Discretion ${ }^{86}$}

It is obviously impossible for the police to enforce every law that exists in statute and case books. The limited number of police personnel, the relative innocuousness of certain forbidden conduct, and the inability of other organs of the legal process-courts, prisons, and prosecutors-to accommodate strict enforcement preclude enforcing every law "to the letter." Thus, police officials must utilize discretion in ascertaining which laws will be enforced. In large part this discretion is shared severally by the community power structure. ${ }^{87}$ Once it is determined which laws are to be enforced, however, the police alone must execute this determination. The most obvious improper use of police discretion occurs when officers continually arrest the members of one race for a violation of a specific law but

80. Reich, supra note 79 , at 1164.

81. See generally Crockelt. supra note 77, at 229.

82. See note 60 supra and accompanying text.

83. SKOLNICK 82.

84. See note 60 supra and accompanying text.

85. Rinella 780. Cf. Jones v. Alfred H. Mayer Co.. 392 U.S. 409, 446 (1968): "'A state court judge in Alabama convicted a Negro woman of contempt of court because she refused to answer him when he addressed her as 'Mary," although she made the simple request to be called 'Miss Hamilton." ${ }^{-\cdots}$

86. See generally. Tieger, Police Discretion and Discriminatory Enforcement. 1971 DUKE L.J. 717.

87. "The police function [is] to support and enforce the interests of the dominant political. social, and economic interests of the town, and only incidentally to enforce the law." Westley, The Police: A Sociological Study of Law. ('ustom, and Morality 38 (unpub. doc. thesis 1951). 
decline to arrest members of another race for the same violation. Several examples are the high incidence of inebriation, ${ }^{88}$ loitering, and resisting arrest violations reported in ghetto areas ${ }^{89}$ as compared to those reported in low-income white areas. Only a minute fraction of the aggregate police-citizen contacts ever receive judicial or other official review. ${ }^{90}$ Thus, the low visibility of police conduct serves to reinforce their virtually untrammelled discretion..$^{91}$

A second aspect of the misuse of police discretion is the practice of "aggressive preventive patrol." ${ }^{2}$ This tactic involves the influx of motorized police corps cruising ghetto neighborhoods without warning and initiating "intensive, often indiscriminate, street stops and searches." 93 Such conduct clearly violates the constitutional safeguards against unreasonable searches and seizure, ${ }^{94}$ may impinge upon the right of association and mobility, and arguably provokes hostile black counterprejudices and attitudes. The benefit gained, if any, in crime prevention must be weighed against the ill will fostered in the black community. This latter consideration weighs heavy since it is axiomatic that without adequate cooperation from the community, police are unable to efficiently accomplish their law enforcement duties ${ }^{95}$ Furthermore, there are strong indications that aggressive preventive patrolling has been employed to supersede, not supplement, ordinary police services and has resulted in a neglect of the latter services..$^{96} \mathrm{~A}$ closely related technique employed by some large city police bureaus is to assign a quota of stop and frisk reports to police patrolling high crime areas. ${ }^{97}$ These quotas result in a

88. Cf. Goldstein, Police Discretion Not to Invoke the Criminal Process: Low Visibility Decisions in the Administration of Justice. 69 YALE L.J. 543, 575 n.66 (1960).

89. See G. Myrdal. AN Anerican Dilemma 968 (Twentieth Anniversary ed., Harper \& Row 1962). It is crucial to distinguish police discrimination from other factors responsible for racially disparate consequences. For example, a middle-class white and a lower-class black may both be arrested for disorderly conduct. The white will be able to post bond, but the black will have to remain in jail. Here the unequal consequences are a result of economic, not racial, differences. There is the possibility, however, that police will arrest blacks with the knowledge tha' raising bail poses serious difficulties for them.

90. See generally Goldstein, supra note 88 , at 575 n.67.

91. See id.; SKolnick 231.

92. Kerner COMm'N Rep. 11-12.

93. Id.

94. See Mapp v. Ohio, 367 U.S. 643 (1961).

95. TASK ForCe: The POLICE 144-45; KeRner COMM'N Rep. $11-4$.

96. Hahn \& Feagin 192.

97. KeR.Ner COMM" $\times$ REP. 11-13. "[R]ace has an undue influence on who is stopped." TASK FORCE: The POLICE 184. 
mandatory number of police-citizen encounters demeaning the character of the recipient and creating residual anti-police sentiments.

The final counterproductive misuse of discretion is the erroneous decision to refuse to retreat from a minor confrontation. Such confrontations may arise in a variety of circumstances, but one documented example discloses the essential characteristics common to all. A Negro improperly parks his car while his wife enters a store. A white policeman questions the double-parking and receives a loud and disrespectful answer from the driver. "Sharp words are exchanged, followed by arrest, blows, and eventual charges of disorderly conduct, resisting arrest, and assault and battery on a policeman." 98 Although the policeman's response in this situation was predictable, ${ }^{99}$ it is nonetheless unfortunate. At the point when the driver became disrespectful, the policeman had the choice of calmly admonishing him to move on or to arrest him for disorderly conduct. The latter course was certain to further exacerbate the driver's uncooperative attitude over the relatively minor issue of improper parking. The inappropriate choice led to unnecessary violence.

Another fertile source of black dissatisfaction with police service is, ironically, the failure of police to provide adequate protection within the ghetto. ${ }^{100}$ The complaints may be roughly divided into two categories. First, police tolerate a much higher degree of illegal activity in black neighborhoods than in suburbia. ${ }^{101}$ Second, calls for assistance from ghetto residents receive less timely responses than calls from white communities. ${ }^{102}$ Excessive crime toleration stems from the police opinion that violence is a common and accepted mode of behavior in the ghetto. Thus, police rationalize that if both actors in an assault are black no harm threatens the black community and no need exists to provide police deterrence. ${ }^{103}$ Furthermore, the high

98. Schwartz, Complaints Against the Police: Experience of the Community Rights Division of the Philadelphia District Attorney's Office. 118 U. PA. L. REv. 1023, 1032 (1970).

99. See notes 40-42 supra and accompanying text.

100. Kerner Comm 'N Rep. 11-21; Krantz \& Kramer, The Urban Crisis and Crime, 50 B.U.L. REv. 343, 344 (1970).

101. KeRner Comis: ReP. 11-21. The ghetto area of Hartford, Connecticut, attracts over one-third of the daylight burglaries in the city yet receives only one of the city's 18 daytime patrol cars. Note. Program Budgeting for Police Departments, 76 YaL: L.J. 822 (1967).

102. Kerner Comm'n Rep. 11-23; Feagin, Home-Defense and the Police, 13 Am. Behav. SCIENTIST 797, 799 (1970). Cleveland police take four times as long to respond to burglary calls from the black district as from their next slowest reaction district. Hahn \& Feagin 189.

103. Goldstein. supra note 88, at 575. 
incidence of violent crimes in ghetto neighborhoods would dissipate limited police resources to the point of ignoring other duties. ${ }^{104}$

Police procedures in ghetto areas attract diametrically opposite criticism. They are accused on the one hand of allowing criminal permissiveness in black areas and of not sponding to calls for assistance. On the other hand, they are blamed for instituting oppressive "aggressive patrol practices" and of verbally or physically mistreating those black residents whom they encounter. The problem is one of major proportions and unusual complexity. Any solution must begin with a more professional police and improved policecommunity relations.

\section{Negro Antipathy Toward Police}

The first two sections of this comment analyzed underlying psycho-sociological causes motivating racial misconduct by police and their resultant manifestations. But one must also understand the attitudinal perspectives with which Negroes view white police. At the outset it should be emphasized that whatever conception the Negro has of white police is shaped partly by his opinion of the larger white community. Negroes justifiably feel that Caucasians have foreclosed them from equal employment, housing, recreational, and educational opportunities, and that regardless of their abilities and efforts they will receive what is left after "Whitey" has taken the cream. ${ }^{105} \mathrm{~A}$ black judge has identified incidents of racism embedded in the American legal system which exacerbate the difficulty facing qualified Negroes searching for suitable employment. One example is the civil service provision permitting anyone of the top three eligible candidates to be chosen for the job, thus providing an opportunity to by-pass qualified Negroes. ${ }^{106}$ Black cognizance of systematic discrimination has engendered extreme bitterness toward white

104. Id.

105. See, e.g., J. Lohman, The Police and Minority Groups 62 (Chi. Park Dist. 1947): MaCord \& Howard, Negro Opinions in Three Riot Cities, 11 Am. Behav. Scientist 24, 25 (1968). Malcolm X sums up this feeling in THE AutoBiography of MaLcolm X 16 (1965):

This was my first lesson about gambling: if you see somebody winning all the time, he isn't gambling, he's cheating. Later on in life. if I were continuously losing in any gambling situation, 1 would watch very closely. It's like the Negro in America seeing the white man win all the time. He's a professional gambler; he has all the cards and the odds stackcd on his side. and he has always dealt to our people from the bottom of the deck. 106. Crocket, supra note 77, at 228. 
A merica. ${ }^{107}$ Cogent evidence of the pervasive dissatisfaction harbored by Negroes against the existing legal system was demonstrated by a 1967 Detroit survey which found that 92 percent of all Negroes interviewed did not believe that "most of the laws on the books are fair to all people." 108 The problem is compounded when Negroes feel that inherently unfair laws are then enforced in a discriminatory manner. ${ }^{109}$

In light of the overwhelming black antipathy toward the white power structure, how does the Negro evaluate the policeman's role within this structure? The negative reaction encountered by white police in black neighborhoods is lucidly portrayed by James Baldwin:

The only way to police a ghetto is to be oppressive. None of the Police Commissioner's men, even with the best will in the world, have any way of understanding the lives led by the people they swagger about in twos and threes controlling. Their very presence is an insult, and it would be, even if they spent their entire day feeding gumdrops to children. They represent the force of the white world, and that world's criminal profit and ease, to keep the black man corralled up here, in his place. The badge, the gun in the holster, and the swinging club make vivid what will happen should his rebellion become overt

... [H]e is facing, daily and nightly, people who would gladly see him dead, and he knows it. There is no way for him not to know it: there are few things under heaven more unnerving than the silent, accumulating contempt and hatred of a people. He moves through Harlem, therefore, like an occupying soldier in a bitterly hostile country; which is precisely what, and where he is, and is the reason he walks in twos and threes. 10

107. A black intellectual after the 1967 Detroit riots expressed the feelings of the black community:

If you know the culture and gain access to the heart of the community, you comc up with one astounding pattern and that is, they hate Whitey - they literally hate Whitey, all of them. And even with the middle-class Negroes-you're not going to get them to say, "Let's go and kill Whitey!" or something like that, you're not going to get that -but l'll tell you what. Try talking to them about their jobs. Where the highest level among many of them is to get to be some kind of supervisor, and they know damn well they're smartcr than the honky who's over them. Get them talking about that sometime .... Everybody, well, not everybody, but particularly the liberals do not want to face the aura of hate that is inside the community. They don't want to deal with it. They don't want to deal with the tremendous racial aspect of what has happened. li's just too ugly.

Grimshaw, Three Views of Urban Violence: Civil Disturbance, Racial Revolt, Class Assault, 11 AM. BEHAV. SCIENTIST 2, 5 (1968).

New Jersey Governor Richard J. Hughes has expressed a different perspective of the race riots: “. . . open rebellion . . . criminal insurrection . . . an atrocity . . plain and simple crime and not a civil rights protest." $1 d$. at 4.

108. Hahn \& Feagin 185.

109. Id.

110. J. BaldwiN, Nobody Knows My Name 65-67 (1961). 
The policeman is thus a symbol of white culture. ${ }^{111}$ In fact, he is the arm of the society which continually and immediately translates rules into actual conduct in the ghetto. It is not difficult to understand why the police bear the brunt of black animosity.

A sampling of polls conducted both before and after the riots of the 1960's elucidates black perception of police service. After the 1965 Watts riot, 41 percent of the black residents placed police service in either "poor" or "not good" categories." In the same year 86 percent of Oakland Negroes opined that police could not be classified as either excellent, fair, or neutral, while 56 percent believed police to be abusive. ${ }^{113}$ In a 1966 Harris Poll, forty-one percent of black respondents in the North and West considered local police more harmful than helpful to black rights and over 80 percent of Detroit Negroes in 1967 believed that police did not enforce the laws equally. ${ }^{114}$ These figures should be compared with a survey indicating that 77 percent of the general public considered police service to be either very good or pretty good. ${ }^{115}$ Finally, the $1964 \mathrm{Harlem}$, the 1965 Watts, and the 1967 Detroit ${ }^{116}$ studies demonstrated that nearly half of the black residents believed police brutality was a serious problem, while a 1965 Gallup poll found that only 9 percent of the general public believed "there [was] any police brutality. . .."117 An overwhelming majority of Negroes consider police to be corrupt and dishonest. ${ }^{118}$ A $1966 \mathrm{St}$. Louis study found that nearly half of that city's Negroes felt most citizens were "afraid" to contact their police. ${ }^{119}$ This latter figure may reflect in part the opinion of many Negroes that even if they do call the police, service will be slow ${ }^{120}$ and hence relatively worthless.

lt is probable that black perceptions of police brutality are not based entirely on actual brutality, but represent a conditioned response. A large portion of the black community in northern ghettos has recently migrated from the South. Many of these Negroes vividly

111. E.g., id.; Fogelson 220-21; Rinella 798.

112. Hahn \& Feagin 183.

113. McCord \& Howard. supra note 105 , at 25.

114. Hahn \& Feagin $183,185$.

115. TASK FORCE: THE POLICE 145.

116. See Hahn \& Feagin 187-88.

117. TASK FORCE: THE POLICE 146.

118. Hahn, supra note 2, at 777 n.2. ("'A A]pproximately ninety percent [of Twelfth Street ghetto residents] asserted that "most Detroit police break the rules for their personal gain." ).

119. TASK ForCE: The POLICE 144.

120. See note 102 supra and accompanying text. 
recollect the brutal nature of southern law enforcement and have transferred their perceptions of southern police to northern law enforcement officials.

Prejudiced, overworked, frustrated, and authoritarian police have been depicted working within a dirty, crime-infested black ghetto emanating an overwhelming hatred of white police. In this charged atmosphere of interracial tension, incidents of brutality by both Negroes and police are inevitable. The remainder of this comment will discuss the federal civil remedies available to redress racially motivated police misconduct.

\section{Federal Civil Remedies for Police Brutality Under Sections 1981 AND 1983}

\section{Section 1983}

The issue of policing the police has received considerable attention in the last decade. A panoply of administrative, ${ }^{121}$ civilian, ${ }^{122}$ state judicial, ${ }^{123}$ and federal judicial remedies ${ }^{124}$ have been proposed and

121. E.g., Schwartz, supra note 98 the author discusses the conflict of interest and inefficacy resulting from having a division of the District Altorney's Office handle police misconduct complaints); Comment, Use of \$ 1983 to Remedy Unconstitutional Police Conduct: Guarding the Guards, 5 HARv. Civ. Rights Civ. LiB. L. Rev. 104 (1970) (the Comment proposed that the court appointed masters or monitors work within the police department and oversee police conduct); Comment, Grievance Response Mechanisms for Police Misconduct, 55 VA. L. Rev. 909, 935-46 (1969).

122. E.g. Barton, Civilian Review Boards and the Handling of Complaints Against the Police, 20 U. TORONTo L.J. 448 (1970): Beral \& Risk, The Administration of Complaints by Civilians Against the Police, 77 Harv. L. R\&v. 499 (1964); Coxe. The Philadelphia Police Advisory Board, 2 L. IN TRans. 179 (1965): Cray. Annotated Bibliography on Police Review Boards. 3 L. IN Trans. 197 (1966); Locke, Police Brutality and (ivilian Review Boards: A Second Look. 44 J. Urban L. 625 (1967): Murdy, Civilian Review Boards in Review, 35 FBI L. ENForCE. BULl. 7 (1966); Norris, Constitutional Law Enjorcement is Ejfective Law Enforcement: Toward a C'oncept of Police in a Democracy and a (itizens' Advisory Board, 43 U. Det. L.J. 203 (1965); Comment, Police-Philadeiphia's Police Advisory Board-. A New Concept in Community Relations, 7 VILL. L. Rev. 656 (1962).

123. See, e.g.. Foote. Tort Remedies for Police Violations of Individual Rights. 39 MiNs. L. Rev. 492 (1965): 55 VA. L. Rev.. supra note 121, at 916-20, 927-28. 930-31: Comment. Tort Liability of Law Enforcement Officers: State Remedies. 29 LA. L. REv. 130 (1968). CJ. Hall. The Law of Arrest in Relation to Contemporary Social Problemts, 3 U. CHI. L. REv. 345 (1936)

124. The feasibility of a class action against police misconduct is explored in Comment. Lawless Law Enforcement, 4 LoY. L. Rev. 161 (197I).

In addition to the federal civil remedies for police misconduct. 18 U.S.C. $\$ 242$ (1964). provides a federal criminal remedy for the "deprivation [under color of law] of any rights, privileges, or immunities secured . . by the Constitution or laws of the United States." While this remedy is available to redress police brutality. certain constraining fact ors have impaired its usefulness. One must prove the defendant possessed a "specific intent" to deprive the grievant of 
with varying degrees of competency examined. The workhorse of federal civil rights litigation is 42 U.S.C. $\S 1983 .{ }^{125}$ The 1961

a constitutional right, not merely a "generally bad purpose." Screws v. United States, 325 U.S. 91,103 (1945). However, an objective test for such intent has been deemed sufficient to sustain a conviction. Crews v. United States, 160 F.2d 746, 750 (5th Cir. 1947). But even if the plaintiff is successful, the statute prescribes a maximum fine of $\$ 1,000$ and one year imprisonment. "[T]he statute has become a fragile weapon in the armory of the Department of Justice." Shapiro, Limitations in Prosecuting Civil Rights Violations, 46 CORNELL L.Q. 532 (1961).

125. Ku Klux Klan Act of April 20, 1871, ch. 22, \& 1, 17 Stat. 13, codified, Revised Statutes of 1878, $\$ 1979$ (2d ed.) now, 42 U.S.C. $\$ 1983$ (1964). In the years immediately following the Civil War the Reconstruction Congress conceived of and passed three Constitutional Amendments. U.S. ConsT. amends. XIII, XIV, XV, and five civil rights acts. Act of April 9, 1866, ch. 3I, § 1, 14 Stat. 27; Act of May 31, 1870, 16 Stat. 140; Act of February 28, 1871, 16 Stat. 433; Ku Klux Klan Act of April 30, 1871, 17 Stat. 13; Act of March 1, 1875, 18 Stat. 335. The purposes of these acts as revealed by legislative history are succinctly stated in R. CARR, Federal Protection of Civil Rights: Quest for a Sword, $37-40$ (1947). This flutry of legislative activity was born of a twin desire to reprimand the southern states for the costly Civil War and to implement the freedom promised the Negro by the Emancipation Proclamation.

The third of the five civil rights acts, presently codified as section 1983 of title 42 of the United States Code, was originally enacted on April 20, 1871. 17 Stat. 13 (1871). 42 U.S.C. $§ 1983$ (1964) provides:

Every person who, under color of any statute, ordinance, regulation, custom, or usage, of any State or Territory, subjects, or causes to be subjected, any citizen of the United States or other person within the jurisdiction thereof to the deprivation of any rights, privileges, or immunities secured by the Constitution and laws, shall be liable to the party injured in an action at law, suit in equity, or other proper proceeding for redress.

Known as the Ku Klux Klan Act, the Anti-lynching Act, and the Third Civil Rights Act, this statute was designed to "enforce the provisions of the Fourteenth Amendment" and to halt the practices of organized bands of Caucasian southerners attempting to deprive the freedmen of their newly acquired rights. It is reasonably clear that the framers intended the Act to apply to private individuals such as Klansmen and not merely to persons acting under "color" of state law. $C f$. CONG. Globe, 42nd Cong., Ist Sess. 353 (1871). See also Gressman, The Unhappy History of Civil Rights Litigation, 50 MiCH. L. REv. 1323, 1339-40 (1952).

In their zeal to protect the rights of the Negro, however, the draftsmen overlooked potential weaknesses in their choice of statutory language. In United States v. Cruikshank, 92 U.S. 542, 554-55 (1875), the Supreme Court held that the first section of the fourteenth amendment applied only to state action, not to private conduct. Accord. Hodges v. United States, 203 U.S. I, 14 (1906). Once the fourteenth amendment was precluded from protecting the freedman from private action, civil rights legislation enacted pursuant to the fifth section thereof was assured a similar fate. In United States v. Harris, 106 U.S. 629 (1882), the Court predictably declared unconstitutional the criminal conspiracy provision of the Ku Klux Klan Act which purported to proscribe lynchings and gang atrocities by private groups. Perhaps the most devastating judicial negation of the civil rights legislation was visited by the Slaughterhouse Cases, 83 U.S. (16 Wall.) $36.74,79$ (1873). There the Court interpreted the privileges and immunities clause of the fourteenth amendment to protect only the incidents of national citizenship, such as the right to sue in federal court and the right to travel to the national capitol, and not to protect the incidents of state citizenship. The privileges and immunities clause of the 1871 Act was accorded the same restrictive interpretation in Cruikshank. Finally, it was not until 1961 that the Supreme Court answered negatively a question as basic as whether exhaustion of state civil rights remedies must precede resort to section 1983 . See note 126 infra and accompanying text.

Given the judicial antipathy toward the reconstruction legislation, it is not surprising that 
landmark case of Monroe v. Pape $e^{126}$ established section 1983 as a viable means of obtaining relief for torts committed by law enforcement officials. In the interim between 1961 and the present, the utility of section 1983 has matured to the point where it is the basis for nearly every federally instituted claim alleging police brutality. ${ }^{127}$

Elements of a Section 1983 Action. Section 1983 explicitly indicates that a proper party plaintiff is "any citizen of the United States or other person within the jurisdiction thereof." $12 x$ The courts, applying this language literally, have allowed aliens to invoke the Act's protection. ${ }^{129} \mathrm{lt}$ is clear that a victim of police brutality qualifies as a plaintiff under the Act. ${ }^{130}$

Although section 1983 provides a cause of action for police brutality, it does not confer jurisdiction. The plaintiff must choose

there were only 21 reported cases predicated on the Ku Klux Klan Act from the date of its inception until 1920. See generally Comment. The Civil Rights Act: Entergence of an Adequate Federal Civil Remedy?, 26 IND. L.J. 361, 363 (1951). Brawner v. Irwin, 169 F. 964.965 (N.D. Ga. 1909), the earliest significant case employing the precursor to section 1983 for redress of police brutality. demonstrates the inimical attitude adopted by the federal courts toward reconstruction legislation. A local police chief had allegedly "cruelly assaulted and beat [en] [the plaintiff, a black womanl, with a whip, cutting her flesh in scars," arrested and imprisoned her. and subsequently released her without filing charges. The court, relying on the Slaughterhouse Cases. held that the "right of an individual to life, liberty, and property, and to be free from molestation" is a right adhering to state citizenship and hence beyond the purview of the privileges and immunities secured by the fourteenth amendment and the Ku Klux Klan Act. Id. at 966. Although the court in Brawner construed the Ku Klux Klan Act with a heavier hand than most courts had, 30 years transpired before the Supreme Court in Hague v. CIO. 307 U.S. 496, 527 (1939), foretold a change in judicial attitude toward the old civil rights acts by interpreting section I979 of the Revised Statutes of 1878 , now 42 U.S.C. \$ 1983, to protect the privileges of free speech and peaceful assembly from inimical state action.

126. 365 U.S. 167 (1961), noted in Sperber, Monroe v. Pape: Redress Under the Civil Rights Acts Redefined, 21 Law in Trans. 197 (1961); Comment. The Civil Rights Acts and Mr. Monroe, 49 CAL. L. Rev. 145 (1961); Note, Constitutional Law: "Under Color Of" Law" and the Civil Rights Act, 1961 DuKe L.J. 452; The Supreme Court. 1960 Term, 75 HARv. L. Rev. 40, 211 (1961); 4 Ariz. L. Rev. 105 (1962); 12 Mercer L. Rev. 410 (1961); 37 N.D..L. REv. 433 (196I); 38 U. DET. L.J. 655 (1961); I5 YAND. L. Rev. 267 (1961). For an analysis of the judicial progeny of Monroe, sce Shapo, Constitutional Tort: Monros v. Pape. and the Frontiers Beyond. 60 Nw. U.L. REv. 277, 297 (1965).

127. Successful damage actions since 1950 under $\S 1983$ againsl police are compiled and summarized in Ginger \& Bell, Police Misconduct Litigation-Plaintiff's Remedies. 15 A v. JUR. TRIALS 555, $580-90$ (1968).

128. See note 125 supra.

129. E.g., Truax v. Raich, 239 U.S. 33,39 (1915).

130. Some question exists whether artificial persons such as corporations fall within the "person" language of 42 U.S.C. \$ 1983. Most courts have answered the issue in the affirmative. The United States, however, is not a "person." See Note. The Civil Rights Act of 1871: Continuing Validity, 40 Notre DA.ME: LAw. 70.74 (1964). 
either sections 1343 or $1331^{131}$ as a jurisdictional springboard into the federal district courts. The jurisdictional requirements of section 1343(3) are satisfied by demanding damages or equitable relief under section 1983 since the latter is "an Act of Congress providing for equal rights of citizens . . .."132 If the plaintiff chooses to premise federal district court jurisdiction on section 1331, he must allege that the matter in controversy exceeds 10,000 dollars and that his cause of action arises under a law of the United States. The second requirement is fulfilled by basing one's claim on section 1983, but the first prerequisite may prove difficult since the value of a civil right arguably is not measurable in dollars and cents. ${ }^{133}$

Section 1983 dictates that "every person" acting under color of law to deprive another of any right secured by the Constitution and laws of the United States "shall be liable to the party injured. ..." 134 The primary prerequisite subjecting one to the sanctions of the Act appears to be that the potential defendant has acted under color of state law. The courts have followed this directive by excluding federal officers ${ }^{135}$ and private individuals ${ }^{136}$ from 1983 coverage. It appeared, nevertheless, that the otherwise sweeping language might be construed literally when Picking v. Pennsylvania $R . R$. held that "Congress gave a right of action sounding in tort to every individual whose federal rights were trespassed upon by any officer acting under pretense of state law." " ${ }^{37}$ But the courts, fearful of a rash of irresponsible suits against members of the legislative, judicial, and executive branches of the government, ${ }^{138}$ have engrafted further exceptions to the clear mandate that "every person" shall be liable. In Tenney v. Brandhove ${ }^{139}$ the Supreme Court declared that the

131. 28 U.S.C. $\$ \S 1331,1343$ (1964).

132. 28 U.S.C. $\$ 1343(3)$ (1964). For a general discussion of jurisdictional aspects of a 1983 cause of action see Note. Civil Procedure: Section (343(3) Jurisdiction and the PropertyPersonal Right Distinction. 1970 DUKE L.J. 819.

133. Cf. Hague v. C.1.O., 307 U.S. 496, 507-08, 529-32 (1939) (opinions of Roberts, J., and Stone, J.).

134. 42 U.S.C. $\S 1983(1964)$.

135. E.g.. Norton v. McShane, 332 F.2d 855 (5th Cir. 1964), cert. denied. 380 U.S. 981 (1965).

136. E.g., Kenney v. Fox, 232 F.2d 288 (6th Cir.), cert. denied, 352 U.S. 855,856 (1956).

137. 151 F.2d 240, 249 (3d Cir. 1945) (emphasis added), decided on remand, 5 F.R.D. 280 (M.D. Pa.), 66 F. Supp. 233 (M.D. Pa. 1946), affd, 160 F.2d 106 (3d Cir.), cert. denied, 332 U.S. 776 (1947), overruled, Bauers v. Heisel, 361 F.2d 581, 584 (3d Cir. 1966), cert. denied. 386 U.S. 1021 (1967).

138. E.g., Burt v. City of New York, 156 F.2d 791.793 (2d Cir. 1946) (Hand, J.).

139. 341 U.S. 367 (1951). 
drafters of the Ku Klux Klan Act did not intend to abolish the common law doctrine of legislative immunity ${ }^{140}$ and that state legislators were not subject to the restrictions of the Act. This thesis has been adopted and expanded by subsequent decisions to exclude state judges, ${ }^{141}$ prosecuting attorneys, ${ }^{142}$ probation officers, ${ }^{143}$ and other quasi-judicial or quasi-legislative officials in the exercise of their official duties. ${ }^{144}$

The issue of whether police are also cloaked with a form of executive or discretionary immunity was answered negatively by Monroe v. Pape. ${ }^{145}$ Thus, a private party alleging police brutality against an individual policeman will not be denied recovery for failure to sue a proper party defendant. But while Monroe did not exempt police from liability, it also held that municipalities and any arm thereof are protected by sovereign immunity. ${ }^{146}$ This holding thus exempts a city and its police department from vicarious liability for the torts of its police-employees. Most police assure that they are judgment-proof by assigning all of their property to their wives; ${ }^{1.7}$ but even if they fail to use such a subterfuge, their low salary precludes the satisfaction of a judgment against them. ${ }^{148}$

Many plaintiffs victimized by police misconduct are thus left without a financially responsible defendant amenable to suit. Since occasional police torts are an inevitable cost of effective law enforcement and the police act as representatives of the municipality or state, rather than in a private capacity, this cost should be borne by the entity most capable of doing so. The municipality can best absorb

140. Id. at 376. Legislative history underlying the 1871 Act indicates Congressional intent to preclude certain immunities as defenses to actions under the Act. See 46 Colum. L. REV. 614 (1946).

141. E.g. Haldane v. Chagnon, 345 F.2d 60I (91h Cir. 1965); Curry v. Ragan, 257 F.2d 449 (5th Cir.), cert. denied. 358 U.S. 851 (1958); Francis v. Crafts, 203 F.2d 809 (Ist Cir.), cert. denied, 346 U.S. 835 (1953). See Pierson v. Ray, 386 U.S. 547 (1967).

142. E.g., Rhodes v. Meyer, 334 F.2d 709 (8th Cir.). cert. denied, 379 U.S. 915 (1964); Stift v. Lynch, 267 F.2d 237 (7th Cir. 1959); Kenney v. Fox. 232 F.2d 288 (6/h Cir.), cert. denied, 352 U.S. 855 (1956). But see Robichaud v. Ronan, 351 F.2d 533 (9th Cir. 1965).

143. E.g., Dunn v. Estes. 117 F. Supp. 146 (D. Mass. 1953).

144. Some question exists whether executive immunity is a defense to a $\$ 1983$ claim. See Norton v. McShane, 332 F.2d 855. 862 (5th Cir. 1964), cert. denied, 380 U.S. 981 (1965).

145. 365 U.S. 167 (1961).

146. Id.

147. Avins. Equal Protection Against L'nnecessary Police Violence and the. Original Understanding of the Fourteenth Amendment: A Comment, 19 BLFtALO L. REv. 599 n.7 (1970).

148. See Hall, supra note 123. at 346-48. 
the costs inflicted upon citizens by the law enforcement process and most equitably redistribute that cost to the citizenry in the form of taxes. Moreover, if a municipality realizes that it must reimburse police brutality victims, it will be more circumspect in hiring police with overly aggressive personalities. But despite supplications for the municipality to bear the costs resulting from the misconduct of its police, ${ }^{149}$ this approach has not been adopted in enforcing section $1983 .{ }^{150}$

Types of Police Misconduct Actionable Under Section 1983. Commentators ${ }^{151}$ and courts ${ }^{152}$ have discussed at length whether the deprivation of any right secured by the original Bill of Rights and applied to the states by way of the fourteenth amendment constitutes a cause of action under section 1983. The Ku Klux Klan Act explicitly provides a remedy for the "deprivation of any rights, privileges, or immunities secured by the Constitution and laws [of the United States]." The Supreme Court in Monroe clarified the breadth of these words by holding that

[a]llegation of facts constituting a deprivation under color of state authority of a right guaranteed by the Fourteenth Amendment satisfies ... the requirement of [section 1983] . . . [T] [Te guarantee against unreasonable searches and seizures contained in the Fourth Amendment has been made applicable to the States by reason of the Due Process Clause of the Fourteenth Amendment. ${ }^{153}$

Since 1961 a number of other amendments have been incorporated into the due process clause of the fourteenth amendment. A natural application of Monroe indicates that a denial of these additional absorbed rights also states a claim under section $1983 .{ }^{154}$ The

149. Smeltz v. Copeland. 440 Pa. 224, 269 A.2d 466, 468 (1970) (Roberts, J., dissenting): Mathes \& Jones. Toward a "Scope of Official Duty" Immunity for Police Officers in Damage Actions, 53 Geo. L.J. 889, 890 (1965); Comment, Tort Liability of Law Enforcement Officers Under Section 1983 of the Civil Rights Act, 30 LA. L. REv. 100, 116-18 (1969).

150. Monroe v. Pape, 365 U.S. 167, 187-92 (1961). The trend in state courts is to abolish sovereign immunity, but several states still adhere to the doctrine. E.g.. Smeltz v. Copeland, 440 Pa. 224, 269 A.2d 466 (1970).

151. E.g., Shapo, supra note 126, at 321; Comment, The Civil Rights Acts and Mr. Monroe, 49 CALIf. L. Rev. 145, 159-61 (1961).

152. E.g., Hague v. C1O. 307 U.S. 496, 514 (1939); Powell v. Workmen's Compensation Bd., 327 F.2d 131, 136-37 (2d Cir. 1964).

153. 365 U.S. 167. 171 (1961).

154. See York v. Story, 324 F.2d 450 (9th Cir. 1963), cert. denied, 376 U.S. 939 (1964) (first amendment violation of right of privacy states fourteenth amendment due process claim under section 1983). The equal protection clause of the fourteenth amendment will also sustain a claim 
significance of this development goes beyond the limited category of cases involving police brutality to override the argument that the Bill of Rights is merely a shield and not a sword. An aggrieved party may fashion a viable remedy by framing a denial of a right secured by the first eight amendments in terms of a section 1983 cause of action.

Facts alleging an unreasonable search and seizure, ${ }^{155}$ unlawful arrest, ${ }^{156}$ or false imprisonment ${ }^{157}$ may thus be posited on the fourteenth amendment to overcome the threshold issue of stating a claim under section 1983. But on what theory should police misconduct involving physical abuse or mere verbal discourtesy be premised? The fundamental constitutional privilege against unreasonable and illegal physical abuse has usually been lounded upon the due process clause of the fifth and fourteenth amendments. ${ }^{158}$

Police Intent. A more difficult question arises when the police misconduct involves merely a slight push or verbal insult. In Monroe the Supreme Court stated that a claim alleging police misconduct sounded in tort and that the Ku Klux Klan Act "should be read against the background of tort liability that makes a man responsible for the natural consequences of his actions." 159 Several courts initially refused to apply the above standard on the fear that it would result in something approaching strict liability for police misconduct. ${ }^{160}$ Police are required to think and act quickly under the pressure of extreme stress and rapidly changing circumstances. Thus, to make them liable for the "natural consequences" of their acts would arguably impair the execution of their duties. Furthermore, federal courts might be deluged with frivolous litigants ${ }^{161}$ demanding officious interference by

under section 1983. Moss v. Hornig. 314 F.2d 89.92 (2d Cir. 1963). Cf. Hucy v. Barloga, 277 F. Supp. 864, 873 (N.D. Ill. 1967).

155. See generally Comment. Civil Rights Act Section 1983 and Illegal Search by State Officials. 10 Stan. L. Rev. 347 (1958).

156. See Daly v. Pedersen, 278 F. Supp. 88 (D. Minn. 1967).

157. Cf. Truitt v. State. 278 F.2d 819, 820 (7th Cir.), cert, denied, 364 U.S. 866 (1960): Bradford v. Lefkowitz, 240 F. Supp. 969 (S.D.N.Y. 1965).

- 158. E.g., Morgan v. Labiak, 368 F.2d 338. 340 (JOth Cir. 1966). But see Jenkins v. Averett. 424 F.2d 1228 (4th Cir. 1970) (claim founded upon violation of fourth amendment).

159. 365 U.S. 167, 187 (1961). In Monroe 13 Chicago policemen broke into plaintiffs home. forced he and his wife at gunpoint to stand naked in the living room. insulted them, struck Mr. Monrœe with a flashlight, and kicked his children.

160. Cf. Hardwick v. Hurley, 289 F.2d 529.530 (7th Cir. 1961). But see Joseph v. Rowlen, 402 F.2d 367 (7th Cir. 1968).

161. See Note. Limiting the Section 1983.4 ction in the Wake of Monroe v. Pape, 82 HARv. L. Rev. 1486: 1493 (1969). But see Chevigny. Section 1983 Jurisdiction: A Reply. 83 Harv. L. REV. 1352, 1354-55 (1970). 
federal courts in state police administration. ${ }^{162}$ In light of these restraining considerations, a district court in Bargainer v. Michal ${ }^{163}$ held that to plead and prove a claim under section 1983 the plaintiff must allege that an ulterior motive or bad purpose existed in the mind of the policeman but not that the policeman had a specific intent to deprive the plaintiff of a particular constitutional right. This standard should be compared with the recent liberal interpretation offered in Jenkins $v$. Averett ${ }^{164}$ where an unarmed black youth, offering no resistance, claimed damages under section 1983 for being shot by a police officer. Although the district court had found the defendant "grossly or culpably negligent," it only sustained the plaintiff's pendent state assault and battery claim, rejecting the section 1983 federal claim. The court of appeals reversed the section 1983 treatment, holding that once a violation of the constitutional right "to be free from unreasonable interference by police officers" 165 has been made out, "a showing of intent to injure is not a further prerequisite to recovery under section 1983." 166 By eliminating the difficult burden of proving subjective intent, the Court's holding permits an aggrieved party to base a claim on the objective standard of "gross negligence." 167

Severity of Police Misconduct. The desire to prevent an aggravation of overcrowded court dockets has led at least one court to establish a minimum level of severity or outrageousness before a police official's misconduct constitutes a section 1983 deprivation. In Daly v..Pedersen ${ }^{168}$ the plaintiff alleged that he was shoved while being

162. Cf. Comment, Federal Comity, Official Immunity, and the Dilemma of Section 1983, 1967 DUKE L.J. 741, 756.

163. 233 F. Supp. 270, 273 (N.D. Ohio 1964). Accord, Striker v. Pancher, 317 F.2d 780, 784 (6th Cir. 1963); Hardwick v. Hurley, 289 F.2d 529, 530 (7th Cir. 1961).

164. 424 F.2d 1228 (4th Cir. 1970), noted in 23 VAND. L. Rev. 1341 (1970).

165. 424 F.2d at 1231 .

166. Id. at 1232. The court went further than necessary in its holding, admitting that it could retain an "intent" requirement, but simply deemed gross and culpable negligence a satisfactory showing of such intent. Id. Moreover, the dissent criticized the court for turning 1983 into a general federal negligence statute. Id. at 1234-35. The majority retorted that it had found arbitrariness, "the raw abuse of power by a police officer." not the infliction of injury in inadvertence or "simple negligence" and refused to speculate about cases where arbitrariness could not be shown. Id. at 1232. It should also be noted that the dissent read $A$ verett narrowly. interpreting it to equate gross and culpable negligence with intent. Id. at 1234.

167. On the successful state claim the plaintiff had originally received only $\$ 448$, "out of pocket expenses." The court ordered an award of further damages for pain and suffering on remand, and left the question of punitive damages open for further consideration. Id. at 1229, 1233.

168. 278 F. Supp. 88.94 (D. Minn. 1967). 
escorted by police down a courthouse hallway. The court compared this "trivial battery at best" with the shocking conduct perpetrated in Screws ${ }^{169}$ and Monroe ${ }^{170}$ and rationalized that "the requisite degree of harm needed to constitute a denial of rights implicit in the concept of ordered liberty" was absent. ${ }^{171}$ The opinion is correct in discouraging the institution of lawsuits by every person whose pride has been injured by a harsh word and mild physical encounter with the police. A logical extension of the court's holding means that minor verbal discourtesies also fail to constitute a denial of rights secured by the fourteenth amendment. But clearly a point exists at which verbal affronts should rise to the level of a constitutional tort. Following the tort theory of section 1983 espoused by Monroe v. Pape ${ }^{172}$ and analogizing to the law of civil defamation, certain insults are as devastating as a physical assault and deserve recompense where plaintiff can prove actual damages. Moreover, in one sense verbal insults are more culpable than minor instances of excessive force. It is inevitable that police will occasionally arrest a person without probable cause or employ slightly more force than is necessary to apprehend a suspect. Such minor mistakes, if they fall within the gray area of reasonable police discretion, are excusable. On the other hand, a virulent verbal assault is never necessary for the successful execution of police duties and can only result in discordant police-civilian relations. An individual subjected to such verbal abuse may respond to the affront, further escalating the tension until physical violence erupts between the protagonists. Given the minimal social benefits from police verbal abuse and the resulting social costs, the fact that no battery accompanies a verbal affront should not preclude a successful action under section 1983.

Section 1981

Until recently section 1983 seemed to offer the only viable federal remedy for police brutality. But within the last two years, plaintiffs

169. 325 U.S. 91 (1945) (a sheriff beating a Negro suspect to death). Of course, Screw's is only applicable to the 1983 context by analogy since it involved a criminal action under what is now 18 U.S.C. \$242 (1964).

170. 365 U.S. 167 (1961).

171. One commentator has suggested that only the "most outrageous" police conduct should sustain an action under section 1983. 30 LA. L. Rev.. supra note 149. at 115. (ontra Cohen v. Norris. 300 l:.2d 24. 30-31 (9th (ir. 1962).

172. Sec note 159 supra and accompanying text. 
have begun to employ a potentially broader and more effective device, section 1981. ${ }^{173}$

Legislative History. The first proposed constitutional amendment of the Reconstruction Congress, the thirteenth amendment, was ratified on December 18, 1865, having as its purpose both the denunciation of the legal status of slavery, and the abolition of the badges and incidents accruing therefrom. ${ }^{174}$ Subsequent to ratification, Senator Trumbull proposed that legislation be enacted to implement the amendment he had authored. On April 9, 1866, this proposal became, over President Johnson's veto, the first of five civil rights acts. ${ }^{75}$ Suggestions were made by opponents of the 1866 Act, however, that the thirteenth amendment was confined to merely abolishing the status of slavery. ${ }^{176}$ If this restrictive reading prevailed, legislation purporting to abrogate the badges of slavery would be broader in scope than the amendment itself, and might be deemed unconstitutional.

The fourteenth amendment was intended to dispel all skepticism as to the constitutionality of the 1866 Act. ${ }^{177}$ In 1870 , shortly after the fourteenth amendment was enacted, Congress reenacted the 1866

173. 42 U.S.C. $\S 1981$ (1964).

174. Slaves were denied the right to worship, contract, acquire or hold property, or to be secure in their personal security. J. TEN Broek. The ANTiSLavery Origins of The Fourteenth AMENDMENT 103, 143-44 (1951).

175. 14 Stat. 27. Section 1 of the Civil Rights Act of 1866 originally provided:

That all persons born in the United States and not subject to any foreign power, excluding Indians not taxed, are hereby declared to be citizens of the United States; and such citizens. of every race and color, without regard to any previous condition of slavery or involuntary servitude, except as a punishment for crime whereof the party shall have been duly convicted. shall have the same right, in every State and Territory in the United States, to make and enforce contracts, 10 sue. be parties, and give evidence, to inherit. purchase. lease. sell, hold. and convey real and personal property. and to full and equal benefit of all laws and proceedings for the security of person and property, as is enjoyed by white citizens, and shall be subject to like punishment, pains, and penalties. and to none other, any law. statute, ordinance, regulation. or custom. to the contrary notwithstanding. (emphasis added)

Section 2 of the 1866 Act now survives as 42 U.S.C. $\S \S 1981$ and 1982 (1964). Section 1981 reads:

All persons within the jurisdiction of the United States shall have the same right in every state and Territory to make and enforce contracts, to sue. be parties, give evidence. and to the full and equal benefit of all laws and proceedings for the security of persons and property as is enjoyed by white citizens, and shall be subject to like punishment. pains, penalties. taxes, licenses, and exactions of every kind, and to no other.

176. J. TENBROEK. supra note 174, at 184.

177. Id. at 185. 
Act, ${ }^{178}$ hopefully quashing doubts as to its constitutionality. The Congressional debates concerning the fourteenth amendment clearly indicate anxiety over the lawless acts of private individuals in the South, ${ }^{179}$ and the amendment was intended by many congressmen to curtail private discrimination as well as state action. ${ }^{180}$ The importance of the legislative development of section 1981 lies in the concerted intent of its authors to reach out and nullify not only the legality of the master-slave relationship per se, but the "custom" "181 of both state officials and private individuals of physically and economically harassing the Negro after he was "freed."

Judicial Development. Sections 1981 and 1982 are now, of course, two separate provisions of Title 42 of the United States Code, but originally both provisions were contained in section one of the Act of April $9,1866 .{ }^{182}$ The two provisions are pari materia and any judicial reference to section 1982 is directly relevant to the status of section 1981. ${ }^{183}$

A number of early Supreme Court cases noted in dicta that sections 1981 and 1982 were inapplicable to the acts of private persons, ${ }^{184}$ but since the legislative history ${ }^{185}$ and plain language of the statutes refute this, the Supreme Court in the landmark case of Jones v. Alfred H. Mayer Co. ${ }^{186}$ declined to read a color-of-state-law requirement into section 1982. In defense to a section 1983 suit, police often allege that their conduct was outside the scope of their official duties and hence not under color of law. Courts have been reluctant to accept this defense, stating that it is questionable whether a man with

178. Enforcement Act of May 31, 1870, ch. 114. § 18, 16 Stat. 140, 144 (1870).

179. L. WARSOFF, Equality and the LaW 109-10 (1938).

180. J. TENBROEK, supra note 174, at 186-87. 208, 220. See L. WARSOFF, supra notc 179, at 189-90; H. FlaCK. The Adoption of the FOURTEenth AMENDMENT 220-21, 232, 245-46, 277 (1908)..Contra, e.g., id. at 243-44.

181. See Kohl, The Civil Rights Act of 1866, Its Hour Come Round at Last. 55 Va. L. Rev. 272. 283-89 (1969).

182. 14 Stat. 27. See note 175 supra.

183. See Gannon v. Action. 303 F. Supp. 1240. 1244 (E.D. Mo. 1969); United States ex rel. Washington v. Chester County Police Depl., 300 F. Supp. 1279. 1280 (E.D. Pa. 1969). Contra Cook v. Advertiser Co., 323 F. Supp. 1212, 1215 (M.D. Ala. 1971). See note 5 supra.

184. See Hurd v. Hodge, 334 U.S. 24. 31 (1948): Corrigan v. Buckley, 271 U.S. 323. 331 (1926): Buchanon v. Warley, 245 U.S. 60. 78-79 (1917): Civil Rights Cases, 109 U.S. 3. 16-17 (1883); Virginia v. Rives, 100 U.S. 313, 317-18 (1879). See also Kentucky v. Powers, 139 F. 452. 476-77 (E.D. Ky. 1905), rev'd. 201 U.S. 1 (1906).

185. J. TENBROECK. supra note 174, at 215-17, 220.

186. 392 U.S. 409 (1968). 
a badge can ever shed his cloak of police power and, purely in a private capacity, beat another person. ${ }^{187}$ However, in those instances where color of law is clearly absent, thereby excluding the defendant from section 1983 coverage, a remedy exists in section 1981 since the latter provision applies to private as well as official conduct. ${ }^{188}$

The class of persons entitled to bring a suit under section 1981 is coterminous with section 1983, section 1981 providing that "[a]ll persons within the jurisdiction of the United States" shall have the equal benefit of the laws, and no reason exists for construing this clear language to mean anything other than what it says. A fundamental advantage, however, inures in premising a police brutality case on section 1981 because of the opportunity to name a financially responsible defendant. Since most police are judgment-proof ${ }^{189}$ and the police department ${ }^{190}$ and city ${ }^{191}$ which employ them are immune from vicarious liability for the torts of their employees under section 1983, a suit under that section is often a futile effort. In United States ex rel. Washington v. Chester County Police Department a district court recently held that the law under section 1981 "is not as clear, crystalized and well-settled as is the judicial gloss on section 1983"; and, therefore, municipalities may be liable for the torts of their law enforcement officials. ${ }^{192}$ The basis for the court's decision appears to be that section 1983 provides that "[e]very person" shall be liable for depriving one of certain rights. Section 1983 is thus addressed to the defendant in a personal sense. In contrast, section 1981 is framed in the affirmative and grants to "[a]ll persons" within the jurisdiction of the United States certain rights. Since the word "persons" is employed in a different context and refers to a different class of people, the court did not feel obliged to follow section 1983 precedent. Although such reasoning may be sheer sophistry, the potential ramifications of the holding are immense. If Chester County is followed generally by other courts, an aggrieved plaintiff for the first time will be assured of recovering the jury-awarded damages for

187. See Basista v. Weir, 340 F.2d 74, 80-81 (3d Cir. 1965).

188. E.g., Scott v. Young, 307 F. Supp. 1005 (E.D. Va. 1969); Gannon v. Action, 303 F. Supp. 1240, 1244 (E.D. Mo. 1969). Contra, Cook v. Advertiser Co., 323 Supp. 1212 (M.D. Ala. 1971).

189. See note 147 supra and accompanying text.

190. United States ex rel. Washington v. Chester County Police Dept., 294 F. Supp. 1157, 1158 (E.D. Pa. 1969).

191. Monroe v. Pape, 365 U.S. 167, 187-92 (196I).

192. 294 F. Supp. 1157, 1159 (E.D. Pa. 1969). 
it provides that "[a]ll persons . . . shall be subject to like punishment, pains ... . and exactions [as enjoyed by white citizens] . . . and to no other." A dominant attribute of slavery was punishment at the will of the master. ${ }^{194}$ This license for cruelty was legalized by slave codes permitting an owner "in discharge of his responsibilities for the care and government of slaves" to inflict physical abuse by "whipping, or beating with a horse whip, cow skin, or putting irons on . . . ."195 After slavery was abolished, southern law enforcement offieials utilized their office to perpetuate the custom of anti-Negro brutality. ${ }^{196}$ Section 1981 's requirement of "like punishment, pains ... [and] no other" relates directly to physical brutality incident to slavery. It thus appears that a restriction upon racially motivated police brutality is embodied in section $1981 .{ }^{197}$

Until the recent Supreme Court case of Sullivan v. Little Hunting Park. Inc. ${ }^{198}$ the issue of whether money damages were recoverable under section $1982^{199}$ remained open. ${ }^{200} \mathrm{~A}$ number of lower federal courts had previously answered the question negatively but without providing a rationale to support their holding. ${ }^{201}$ In contrast, a few courts had already inferred a right to money damages in a section 1981 action from section $1988 .{ }^{202}$ Speculation on this matter as to

judicial construction during the first 50 to 70 years of its existence. The present trend of judicial construction as exemplifed by Jones $v$. Alfred $H$. Mayer Co.. however, is to enforce the "plain and unambiguous terms" of the Civil War legislation. 392 U.S. 409.420 (1968) (re: § 1982). A fair construction of the plain, unambiguous terms of section 1981 dispells any notion of a racial membership requirement.

194. W. Dubois. Black Reconstruction IN America 10 (1935) ("Slaves were not considered men . . . they could be punished at will.")

195. See J. TENBROECK. supra note 174. at 103 n.3.

196. Cf. Brawner v. Irwin, 169 F. 964.966 (C.C. N.D. Ga. 1909).

197. See United States ex rel. Washington v. Chester County Police Dept.. 300 F. Supp. 1279 (E.D. Pa. 1969).

198. 396 U.S. 229 (1970), noted in 44 TLL. L. REV. 820 (1970).

199. 42 U.S.C. \& 1982 (1964).

200. See Jones v. Alfred H. Mayer Co.. 392 U.S. 409. 414-15 n. 14 (1968).

201. E.g. Hanna v. Home ins. Co.. 281 F.2d 298. $303 \mathrm{~S}(5$ th (ir. 1960), cert. denied. $36 \overrightarrow{5}$ U.S. 838 (1961): cj. Paynes v. Let. 239 F. Supp. 1019. 1022 (l..D. La. 1965) (re: $\$ 1981$ ), rev'd on other grounds. 377 F.2d 61. 64.65 (5th (ir. 1967) (re: \$ 1985): Watson v. Devlin, $167 \mathrm{~F}$. Supp. 638.640 (t.D. Mich. 1958). affd. 268 F.2d 211 (6th (iir. 1959).

202. 42 U.S.C. \$ 1988 (1964). See Ho Ah Kow v. Nunan (The Queue Case). 12 Fed. (as. 252 (Case No. 6.546) (C.C.D. Cal. 1879) (granting judgment 10 plaintiff on defendant's demurrer to plaintifrs complaint. in an action for damages): United States ex rel. Washington v. Chester County Police Dept.. 300 F. Supp. 1279. 1282 (E.D. Pa. 1969). 
successful litigation of a difficult police brutality case. Chester County will surely encourage the initiation of a greater number of suits against police and thus promote the first effective private remedy for police misconduct.

The statutory language of section 1981 lends itself particularly to a cause of action based on racially motivated police brutality ${ }^{193}$ since

193. Section 1981 applicability to other than racially motivated misconduct is questionable. In Agnew v. City of Compton the court stated that an allegation that one was deprived of a "right which, under similar circumstances. would have been accorded a person of a different race" is essential to state a cause of action under sections 1981 and 1982.239 F.2d 226. 230 (9th Cir. 1956), cert. denied, 353 U.S. 959 (1957), overruled, Cohen v. Norris, 300 F.2d 24, 29 (9th Cir. 1962). Accord, Quarles v. Texas, 312 F. Supp. 835. 839 (S.D. Tex. 1970); A mbrek v. Clark, 287 F. Supp. 208, 210 (E.D. Pa. 1968); cf. Falk v. Wilson. 313 F. Supp. 727, 728 (D. Del. 1970). Agnew premised this racial motivation requirement on several early Suprcme Court cases, see Snowden v. Hughes. 321 U.S. I (1944); Hague v. CIO. 307 U.S. 496 (1939), and on the purpose of the 1866 Civil Rights Act to assure cquality of rights between races. Additional support is found in the section 1981 language providing that "[a]ll persons . . . shall have the . . full and equal benefit of all laws . . . as is enjoyed by white citizens . . . 42 U.S.C. $\& 1981$ (1964) (emphasis added). See note 172 supra. The reference to "white persons" instills racial overtones into the Act, thus inviting a court to find a racial requirement. It is submitted, however, that several considerations indicate that such an interpretation is an unwarranted judicial gloss on the $1866 \mathrm{Act}$.

The Act of April 9, 1866, originally provided that all citizens "of every race and color" are entitled to the equal benefit of the laws "as is enjoyed by white citizens." Ch. $31, \$ 1,14$ Stat. 27. Thus, persons of any race were entitled to invoke the protection of the Act. See Gannon v. Action, 303 F. Supp. 1240, 1244 (E.D. Mo. 1969). Moreover, the Congressional debates reveal an intent to protect not only the newly freed Negro. but also his white sympathizers. $J$. TEN BROECK, supra note 174, at 161-62. If a white should be harassed by fellow whites antagonistic to black freedom, the Caucasian victim was entitled to employ the 1866 Act to vindicate his injury. The congressional intent is clearly contrary to Agnew since such an aggrieved white would clearly not be "deprived of a right which, under similar circumstances, would have been accorded a person of another race." $239 \mathrm{~F} .2 \mathrm{~d}$ at 230 . In fact, the converse is true. A black in similar circumstances would probably have incurred even greater harm. Since the framers of the 1866 Act intended the white sympathizer to be protected by their legislation, the strict "racial membership" requirement of Agnew is erroneous.

The 1905 circuit court case of Kentucky v. Powers, 139 F. 452, 494-95 (C.C. E.D. Ky. 1905), construed the predecessor to section 1981 in a manner consistent with the theory adopted by this comment. In Powers a white alleged the denial of the equal protection of the laws through the systematic exclusion by a state court of those jurors who were of the same political party as the defendant. Although the motivating force behind this denial of the petitioner's rights was political, not racial, the court sustained the claim. The cogent interpretation offered by Powers is supported by the language of the statute. The plain, explicit, and unambiguous terms of section 1981 provide that "[a]Il persons . . . shall have the . . . right . . . to the full and equal benefit of all laws." The subsequent words "as is enjoyed by white citizens" merely establish an objective standard which qualifies the immediately preeeding phrase-"to the full and equal benefit of all laws." Thus, the two phrases may be paraphrased to read-all persons shall have the full and equal benefits of the laws enjoyed by white citizens. Construed in this manner, no element of racism appears in the statute as a prerequisite to stating a valid claim.

As discussed earlier, see note 125 supra, the Reconstruction legislation was subjected to strict 
section 1982 ended when the Court declared in Sullivan ${ }^{203}$ that notwithstanding the silence of section 1982 regarding damages, a money award would lie thereunder. The basic rationale for the Court's holding was the rule of statutory construction that "the existence of a statutory right implies the existence of all necessary and appropriate remedies." ${ }^{204}$ The Court's disposition of the issue appears unassailable from both the standpoint of legislative interpretation and public policy and complements the previous Supreme Court treatment accorded the 1866 Civil Rights Act in Jones v. Alfred $H$. Mayer Co.

The only remaining question is whether section 1981, like section 1982, should be construed to have an implied remedy. The rationale of Sullivan that a statutory right implies all appropriate remedies is certainly equally applicable to section 1981. Furthermore, the Court in Sullivan read 42 U.S.C. $\S 1988$ to permit the utilization of both federal and state damage rules to effectuate the policies subsumed within the Reconstruction Period civil rights acts. ${ }^{205}$ The policy of protecting persons in the enjoyment of their civil rights could hardly be effectuated without supplying a remedy for the federal rights contained in section 1981. ${ }^{206}$ Finally, there appears no reason to provide a remedy for section 1982, and yet decline to do so for section 1981 since both provisions originally constituted an organic, single entity in the 1866 Civil Rights Act and are structurally complementary.

\section{CONCLUSION}

Within the last three years a number of significant cases have revitalized the long dormant Reconstruction Period civil rights acts. The most far-reaching was Jones v. Alfred H. Mayer Co., which held section 1982 to apply to private individuals. Sullivan v. Little Hunting Park, Inc. quickly followed and provided an effective damage remedy to implement Jones. Significantly for civil actions against racially motivated police misconduct, the Fourth Circuit held in Jenkins $v$.

203. 396 U.S. 229. 238-40 (1970).

204. Id. at 239 .

205. 396 U.S. 229.240 (1970).

206. See notes $175 \& 182$ supra and accompanying text. 
$A$ veret $t^{207}$ that an allegation of intent is not required for a section 1983 police misconduct action. ${ }^{20 x}$ In United States ex rel. Washington $v$. Chester County Police Department, ${ }^{209}$ a district court found the defense of sovereign immunity in a section 198 I police brutality case to be irrelevant. ${ }^{210}$ The net effect of these decisions is greater than the sum of its parts. An attitude of judicial liberalism is resurrecting an entire system of "legislation long considered moribund. The Reconstruction Period civil rights acts are phrased in "sweeping terms,"211 and the courts are finally giving effect to the "plain and unambiguous terms" 212 contained therein, notwithstanding the "revolutionary" 113 consequences.

The relevance of such judicial liberalism is the appearance of a means of redressing one of the most crucial problems facing America today. The strain between Negroes and the white police who patrol the A merican black ghettos occasionally ignites into wholesale civil disorder. Those brief encounters highlight a pervasive underlying division between black and white America. Hopefully, by providing an effective means under the law for controlling police abuse and compensating the abused, Congress and the judiciary have promoted improved interracial relationships and closed the gap between the two Americas.

207. 424 F.2d 1228 (4th Cir. 1970).

208. Id. at 1232.

209. 294 F. Supp. 1157 (E.D. Pa. 1969).

210. Id. at 1158 .

211. Jones v. Alfred H. Mayer Co., 392 U.S. 409, 422 (1968).

212. Id. at 420.

213. Id. at 422 . 
